\title{
Translation and cross-cultural adaptation of the Brazilian Portuguese version of the Driving Anger Scale (DAS): long form and short form
}

\author{
Tradução e adaptação transcultural da versão brasileira da Driving Anger Scale \\ (DAS): forma longa e forma curta
}

Jessye Almeida Cantini, ${ }^{1}$ George Oliveira Santos,${ }^{1}$ Eduardo de Carvalho Machado, ${ }^{1,2}$ Antonio Egídio Nardi, ${ }^{1}$ Adriana Cardoso Silva ${ }^{1}$

\begin{abstract}
Introduction: Driving anger has attracted the attention of researchers in recent years because it may induce individuals to drive aggressively or adopt risk behaviors. The Driving Anger Scale (DAS) was designed to evaluate the propensity of drivers to become angry or aggressive while driving. This study describes the cross-cultural adaptation of a Brazilian version of the short form and the long form of the DAS.

Methods: Translation and adaptation were made in four steps: two translations and two back-translations carried out by independent evaluators; the development of a brief version by four bilingual experts in mental health and driving behaviors; a subsequent experimental application; and, finally, an investigation of operational equivalence.

Results: Final Brazilian versions of the short form and of the long form of the DAS were made and are presented.

Conclusions: This important instrument, which assesses driving anger and aggressive behaviors, is now available to evaluate the driving behaviors of the Brazilian population, which facilitates research in this field.
\end{abstract}

Keywords: Cross-cultural adaptation, psychometrics, automobile vehicles, automobile driving.

\section{Introduction}

Driving may trigger many emotions in individuals, such as satisfaction, fear, anxiety and anger. Anger in particular has attracted the attention of researchers in

\section{Resumo}

Introdução: A raiva na direção de veículos tem atraído a atenção de pesquisadores nos últimos anos, pois pode induzir as pessoas a dirigirem agressivamente ou a adotarem comportamentos de risco. A Driving Anger Scale (DAS) foi criada a fim de avaliar a propensão de motoristas a se tornarem agressivos ou raivosos enquanto dirigem. Este estudo descreve a adaptação transcultural de uma versão brasileira da forma longa e da forma curta da DAS.

Método: O processo consistiu em quatro passos: duas traduções e duas retrotraduções elaboradas por avaliadores independentes; elaboração de uma versão sintética por quatro especialistas em saúde mental e comportamentos na direção bilíngues; posterior aplicação experimental; e, finalmente, investigação da equivalência operacional.

Resultados: Foram definidas e são apresentadas as versões finais da forma longa e da forma curta da DAS em português brasileiro.

Conclusões: Este importante instrumento, que mensura a raiva na direção e comportamentos agressivos, está agora disponível para avaliar os comportamentos na direção da população brasileira, facilitando a pesquisa nesse campo de estudo.

Descritores: Adaptação transcultural, psicometria, veículos automotores, condução de veículos.

recent years, because it may induce individuals to drive aggressively or adopt risk behaviors. ${ }^{1,2}$

Dahlen et al. ${ }^{1}$ found that anger is a personality trait that may explain a variety of risk behaviors. As a personality trait, driving anger may be linked to the

\footnotetext{
${ }_{1}^{1}$ Panic \& Respiration Laboratory, Institute of Psychiatry, Universidade Federal do Rio de Janeiro (UFRJ), Rio de Janeiro, RJ, Brazil. ${ }^{2}$ Physical Activity Neuroscience Laboratory, Graduate Program in Physical Activity Sciences, Universidade Salgado de Oliveira (UNIVERSO), Niterói, RJ, Brazil.

Financial support: none.

Submitted Apr 03 2014, accepted for publication Nov 25 2014. No conflicts of interest declared concerning the publication of this article.

Suggested citation: Cantini JA, Santos GO, Machado EC, Nardi AE, Silva AC. Translation and cross-cultural adaptation of the Brazilian Portuguese version of the Driving Anger Scale (DAS): long form and short form. Trends Psychiatry Psychother. 2015;37(1):42-46. http://dx.doi.org/10.1590/2237-6089-2014-0008
} 
propensity to become aggressive or angry while driving and may be analyzed especially when individuals with and without this trait are compared..$^{3,4}$

Deffenbacher et al. ${ }^{5}$ developed the Driving Anger Scale (DAS) to evaluate the propensity of drivers to become angry or aggressive while driving. This instrument has been used in many studies around the world, and findings have suggested that there is a positive association between risk behaviors and driving aggression. ${ }^{6}$ Moreover, Sullman \& Stephens ${ }^{1}$ found that the DAS is able to identify situations that might lead to accidents.

There are two versions of the DAS: the short form and the long form. The short version is one-dimensional and consists of 14 items. The 33-item long version is divided into six subscales: discourtesy (9 items), illegal driving (4 items), hostile gestures (3 items), slow driving (6 items), traffic obstruction ( 7 items) and police presence (4 items). In both versions, respondents should imagine the incidents described and grade the anger level that each situation would induce. The DAS uses a 5-point Likert-like scale (not at all, a little, some, much and very much). The DAS short form yields a single score and is useful for a brief evaluation of driving anger. The DAS long form, in turn, provides specific data about each of its subscales and may be more useful when a detailed data analysis is needed.

The psychometric properties of the 14-item version of the DAS show an alpha reliability between 0.80 and 0.92 . Studies examining the 10 -week test-retest reliability found an alpha of $0.84 .5,7,8$ The 33 -item version has an alpha reliability of $0.90 .^{8}$ This study describes the cultural adaptation of the two DAS versions for the Brazilian population.

\section{Methods}

Permission to cross-culturally adapt the scale for Brazilian Portuguese was requested from the original author of the DAS. After his permission was obtained, we began a four-step process based on the model proposed by Herdman et al. ${ }^{9}$ The steps were: translation, back-translation, semantic equivalence analysis and experimental application.

The translation was made by two independent bilingual translators ( $\mathrm{T} 1$ and $\mathrm{T} 2$ ) that had no previous contact with the scale. After that, two other translators performed a back-translation from Brazilian Portuguese to English (B1 and B2).

The semantic equivalence analysis was performed by four bilingual mental health experts: two of the experts had a vast knowledge of specific psychometric instruments, and the other two were specialists on driving behavior. Comparisons between the translations, back-translations and the original content of the DAS were made to examine the equivalence of the texts. A synthetic version of each item of the instrument was created from the comparison between the translations and the original statement. To examine the synthetic version and the partial translations ( $T 1$, T2, B1 and B2), please write to the corresponding author (contact details at the end of the paper).

After this step, the Brazilian version of the DAS was applied experimentally to assess whether it was understood by individuals in the general Brazilian population. This version of the scale was answered by 15 adults (10 men and 5 women). All were able to drive and had different educational levels: 5 had university degrees, 5 had completed secondary education and 5 had completed primary education.

This study was approved by the Research Ethics Committee of the Institute of Psychiatry of Universidade Federal do Rio de Janeiro, Rio de Janeiro, Brazil (CAAE protocol no. 0028.0.249.000-07). All respondents involved in the experimental application of the Brazilian Portuguese version of the DAS were informed of the objectives of the study and signed an informed consent form.

\section{Results}

When preparing the synthetic version, the experts sometimes considered one of the translations and often considered a combination of the two translations. The two translations were occasionally similar, and in such cases, both versions were used. For some items, changes were made to the sentences suggested by the translators to improve the semantic equivalence between the questions in the original scale and in the Brazilian version of the DAS.

The specialists identified several items that might be misunderstood. When there was any question about the meaning of an item, the original author was consulted for an additional explanation to preserve the semantic characteristics of the original instrument. In the items "Someone in front of you does not start up when the light turns green" and "Someone runs a red light or stop sign," the specialists realized that the term "lights" could be translated in different ways ("luz," "sinal de trânsito," "semáforo," "sinaleira"). The authors decided to keep the structure "sinal de trânsito (semáforo/sinaleira)" when referring to the term "lights" to reduce the chances of comprehension problems due to the many linguistic variations within the Brazilian territory. Furthermore, the 
term "mountain road" in the question "A slow vehicle on a mountain road will not pull over and let people by" was translated as "estrada de montanha," but we decided to use the term "serra" instead.

In general, the respondents of the experimental application of the Brazilian Portuguese version of the DAS had no problems understanding the questionnaire. However, for the questions "You pass a radar speed trap" and "A police officer pulls you over," two individuals questioned the contextual conditions, that is, whether they should consider conditions to be normal, or if there were any changes, such as speeding. To solve this problem, a small adjustment was made to the statement.

After performing these changes, the DAS was administered again using 5 new respondents of both sexes and different educational levels. According to these results, we believe that the Brazilian version of the DAS is suitable to be used in studies about driving behaviors and anger of Brazilian drivers.

The final versions of the scale in Brazilian Portuguese are presented in Tables 1 and 2 .

Table 1 - The Driving Anger Scale (long form) in Brazilian Portuguese

Descrição: Abaixo estão várias situações que você pode encontrar quando está dirigindo em situações consideradas normais. Tente imaginar que os incidentes descritos estão realmente acontecendo com você, e então indique a intensidade de raiva que cada situação provocaria em você. Marque sua resposta preenchendo o quadrado correspondente à direita.

\begin{tabular}{|c|c|c|c|c|c|}
\hline & Nada & Pouca & Razoável & Muita & Muitíssima \\
\hline 1. Alguém à sua frente não avança quando o sinal (semáforo/sinaleira) verde acende. & & & & & \\
\hline 2. Alguém está dirigindo rápido demais para as condições da via. & & & & & \\
\hline 3. Um pedestre caminha lentamente pelo meio da rua, retardando você. & & & & & \\
\hline $\begin{array}{l}\text { 4. Alguém está dirigindo muito lentamente num trecho de ultrapassagem, retendo } \\
\text { todo o trânsito. }\end{array}$ & & & & & \\
\hline 5. Alguém está dirigindo muito próximo a seu parachoque traseiro. & & & & & \\
\hline 6. Alguém está "costurando" o trânsito. & & & & & \\
\hline 7. Alguém lhe corta na autoestrada. & & & & & \\
\hline 8. Alguém lhe corta e toma a vaga de estacionamento que você estava esperando. & & & & & \\
\hline 9. Alguém está dirigindo mais devagar do que o razoável para o fluxo do trânsito. & & & & & \\
\hline $\begin{array}{l}\text { 10. Um veículo lento na subida da serra não oferece passagem para os demais } \\
\text { motoristas passarem. }\end{array}$ & & & & & \\
\hline 11. Você vê um carro da polícia observando o trânsito em um esconderijo. & & & & & \\
\hline 12. Alguém dá marcha ré em sua direção sem olhar. & & & & & \\
\hline 13. Alguém avança o sinal (semáforo/sinaleira) vermelho ou a placa de "pare". & & & & & \\
\hline 14. Alguém vindo em sua direção à noite não reduz os faróis. & & & & & \\
\hline 15. À noite, alguém está dirigindo atrás de você com farol alto. & & & & & \\
\hline 16. Você passa por um radar de velocidade. & & & & & \\
\hline 17. Alguém aumenta a velocidade quando você tenta ultrapassá-lo. & & & & & \\
\hline 18. Alguém demora ao estacionar, atrasando o trânsito. & & & & & \\
\hline 19. Você está preso no congestionamento. & & & & & \\
\hline $\begin{array}{l}\text { 20. Em uma via com várias faixas, alguém te corta quando não há ninguém atrás } \\
\text { de você. }\end{array}$ & & & & & \\
\hline 21. Alguém faz um gesto obsceno para você por causa da sua maneira de dirigir. & & & & & \\
\hline 22. Você atinge um buraco profundo não sinalizado. & & & & & \\
\hline 23. Um carro de polícia está dirigindo no trânsito perto de você. & & & & & \\
\hline 24. Alguém buzina para você por causa da sua maneira de dirigir. & & & & & \\
\hline 25. Alguém está dirigindo além do limite de velocidade. & & & & & \\
\hline $\begin{array}{l}\text { 26. Você está dirigindo atrás de um caminhão que tem material oscilando em sua } \\
\text { traseira. }\end{array}$ & & & & & \\
\hline 27. Alguém grita com você por causa da sua maneira de dirigir. & & & & & \\
\hline 28. Um ciclista está andando no meio da pista e congestionando o trânsito. & & & & & \\
\hline 29. Um policial manda você encostar. & & & & & \\
\hline 30. Você está dirigindo atrás de um veículo que está soltando muita fumaça. & & & & & \\
\hline 31. Um caminhão joga areia ou cascalho no carro que você está dirigindo. & & & & & \\
\hline $\begin{array}{l}\text { 32. Você está dirigindo atrás de um caminhão grande e não consegue ver ao redor } \\
\text { dele. }\end{array}$ & & & & & \\
\hline 33. Você se depara com construções e desvios na estrada. & & & & & \\
\hline
\end{tabular}

44 - Trends Psychiatry Psychother. 2015;37(1) 
Table 2 - The Driving Anger Scale (short form) in Brazilian Portuguese

Descrição: Abaixo estão várias situações que você pode encontrar quando está dirigindo em situações consideradas normais. Tente imaginar que os incidentes descritos estão realmente acontecendo com você, e então indique a intensidade de raiva que cada situação provocaria em você. Marque sua resposta preenchendo o quadrado correspondente à direita.

\begin{tabular}{|c|c|c|c|c|c|}
\hline & Nada & Pouca & Razoável & Muita & Muitíssima \\
\hline 1. Alguém está "costurando" o trânsito. & & & & & \\
\hline $\begin{array}{l}\text { 2. Um veículo lento na subida da serra não oferece passagem para os demais } \\
\text { motoristas passarem. }\end{array}$ & & & & & \\
\hline 3. Alguém dá marcha ré em sua direção sem olhar. & & & & & \\
\hline 4. Você passa por um radar de velocidade. & & & & & \\
\hline 5. Alguém faz um gesto obsceno para você por causa da sua maneira de dirigir. & & & & & \\
\hline 6. Um policial manda você encostar. & & & & & \\
\hline 7. Um caminhão joga areia ou cascalho no carro que você está dirigindo. & & & & & \\
\hline $\begin{array}{l}\text { 8. Alguém avança o sinal de trânsito (semáforo/sinaleira) vermelho ou a placa } \\
\text { de "pare". }\end{array}$ & & & & & \\
\hline 9. Alguém buzina para você por causa da sua maneira de dirigir. & & & & & \\
\hline $\begin{array}{l}\text { 10. Você está dirigindo atrás de um caminhão grande e não consegue ver ao } \\
\text { redor dele. }\end{array}$ & & & & & \\
\hline 11. Um ciclista está andando no meio da pista e congestionando o trânsito. & & & & & \\
\hline 12. Você está preso no congestionamento. & & & & & \\
\hline 13. Alguém aumenta a velocidade quando você tenta ultrapassá-lo. & & & & & \\
\hline 14. Alguém demora ao estacionar, atrasando o trânsito. & & & & & \\
\hline
\end{tabular}

\section{Discussion}

Driving anger has been extensively studied in the past ten years, and its impact on individual behavior may affect road safety. ${ }^{10}$ According to the American Automobile Association, ${ }^{8}$ in the early 1990s, aggressive driving behaviors were responsible for about 200 deaths and 12,000 traffic accidents. Furthermore, one in two serious accidents was due to aggressive driving behaviors. ${ }^{10}$ For every accident resulting from aggressive actions, there may be numerous other instances of anger in traffic, such as driving too close to the back of another car, angrily cutting off other vehicles and making offensive gestures. ${ }^{8}$

Driving anger may also be induced by environmental conditions, such as the driver's anonymity and congested or heavy traffic. ${ }^{7}$ Moreover, individual characteristics may be important factors in inducing rage while driving. Some authors ${ }^{1,5,7}$ have found that individuals differ in their tendencies to become angry or aggressive when provoked or when feeling frustrated while driving. This finding suggests that anger may be a personality trait that leads to greater intolerance to certain situations, thereby causing aggressive behaviors.

Other instruments, such as the Propensity of Angry Driving Scale (PADS) ${ }^{11}$ focus on driving anger within the context of the state-trait theory. However, in addition to assessing anger as a personality trait in drivers, the DAS is unique in that it also identifies situations in which accidents almost occurred. ${ }^{2}$
Working with two translators and two backtranslators during cross-cultural adaptation of the DAS helped the team of experts reach a satisfactory semantic equivalence to the original instrument. This method also ensured that the differences between the two versions were discussed to define appropriate translations.

The analysis of the experimental application revealed that the questions of the Brazilian version of the DAS were understood by individuals of any educational level. However, small adjustments were made to solve interpretation problems raised by the situational context in some items. Having made these changes, we believe that the instrument is now suitable for research about driving anger in the general Brazilian population.

Cross-cultural adaptation is important when translating an instrument originally created in another language. ${ }^{12}$ The DAS has satisfactory psychometric properties, has been adapted and validated in several countries and has been used in many studies with diverse samples of individuals with driving anger and aggressive behaviors. ${ }^{2,6,13,14}$ The Brazilian version of the DAS may significantly contribute to this field of study in Brazil. Future studies should assess the validity and reliability of this instrument.

\section{Conclusion}

This study described the cross-cultural adaptation of the long and short forms of the DAS to Brazilian Portuguese. Four steps were followed, according to the 
recommendations found in the literature: translation, back translation, semantic equivalence analysis and experimental application. The semantic equivalence between the original scale and the Brazilian Portuguese version was satisfactory. Therefore, this important instrument, which assesses driving anger and aggressive behaviors, has proven to be adequate for use in the Brazilian population. This finding fills a significant gap in this field of study and may contribute to the development of future studies about driving behaviors.

\section{References}

1. Dahlen ER, Martin RC, Ragan K, Kuhlman MM. Driving anger, sensation seeking, impulsiveness and boredom proneness in the prediction of unsafe driving. Accid Anal Prev. 2005;37:341-8.

2. Sullman MJM, Stephens AN. A comparison of the Driving Anger Scale and the Propensity of Angry Driving Scale. Accid Anal Prev. 2013;58:88-96.

3. Deffenbacher JL, Deffenbacher DM, Lynch RS, Richards TL. Anger, aggression and risky behavior: a comparison of high and low anger drivers. Behav Res Ther. 2003;41:701-18.

4. Dahlen ER, Ragan KM. Validation of the Propensity for Angry Driving Scale. J Safety Res. 2004;35:557-63.

5. Deffenbacher JL, Oetting ER, Lynch RS. Development of a Driver Anger Scale. Psychol Rep. 1994;74:83-91.

6. Villieux A, Delhomme P. Driving Anger Scale, French adaption: further evidence of reliability and validity. Percept Motor Skills. 2007; 104:947-57.
7. Deffenbacher JL, Huff ME, Lynch RS, Oetting ER, Salvatore NF. Characteristics and treatment of high-anger drivers. J Couns Psychol. 2000;47:5-17.

8. Deffenbacher JL, Lynch RS, Oetting ER, Yingling DA. Driving anger: correlates and a test of state-trait theory. Pers Indiv Differ. 2001;31:1321-31.

9. Herdman M, Fox-Rushby J, Badia X. A model of equivalence in the cultural adaptation of HRQOl. instruments: the universalist approach. Qual Life Res. 1998;7:323-35.

10. Deffenbacher JL, Lynch RS, Oetting ER, Swaim RC. The Driving Anger Expression Inventory: a measure of how people express their anger on the road. Behav Res Ther. 2002;40:717-37.

11. DePasquale JP, Geller ES, Clarke SW, Littleton LC. Measuring road rage: development of the Propensity for Angry Driving Scale. J Safety Res. 2001;32:1-16.

12. Gserjing, L, Caplehorn, JR, Clausen, T. Cross-cultural adaptation of research instruments: language, setting, time and statistical considerations. BMC Med Res Methodol. 2010;10:13.

13. Lajunen $T$, Parker $D$. Are aggressive people aggressive drivers? A study of the relationship between self-reported general aggressiveness, driver anger and aggressive driving. Accid Anal Prev. 2001;33:243-55.

14. Iverson $H$, Rundmo $T$. Personality risky driving and accident involvement among Norwegian drivers. Pers Indiv Dif. 2002;33:1251-63.

\section{Correspondence:}

Jessye Almeida Cantini

Laboratório de Pânico e Respiração - IPUB/ UFRJ

Rua Visconde de Pirajá, 407/702

22410-003 - Rio de Janeiro, RJ - Brazil

Tel.: + 55 (21) 7941.2626

E-mail: jessyecantini@yahoo.com.br 